\title{
Ataxic Gait and Back Pain in an Immunocompetent 5-Year- Old Boy
}

\author{
Miller Rebecca ${ }^{1 *}$, Lakkunarajah Sinduja ${ }^{1}$ and Goldwasser Bernard ${ }^{2}$ \\ ${ }^{1}$ Department of Pediatrics, Jacobi Medical Center, Albert Einstein College of Medicine, Bronx, NY, USA \\ ${ }^{2}$ Department of Radiology, Jacobi Medical Center, Albert Einstein College of Medicine, Bronx, NY, USA
}

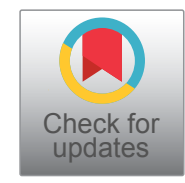

\begin{abstract}
Bartonella henselae is a Gram-negative bacterium and the causative agent of Cat Scratch Disease (CSD). Atypical presentations of $B$. henselae that involve musculoskeletal, hepatosplenic, or neurologic systems are rare. In this case report, we describe a case of $B$. henselae osteomyelitis involving the thoracic spine at the level of T2, complicated by both hepatic and splenic granulomas in a 5 -year-old generally healthy male patient. Although $B$. henselae is a rare cause of osteomyelitis, it should be considered in patients with a possible cat exposure, who present with fever, pain, and lymphadenopathy.
\end{abstract}

\section{Keywords}

Bartonella, Immunocompetent, Osteomyelitis

\section{Introduction}

Bartonella henselae is a Gram-negative bacillus that is known to cause cat scratch disease (CSD), usually in children [1]. The organism can be transmitted by kittens or puppies, but most of the cases are usually from kittens under one year of age [1]. The organism is usually found in the bloodstream of these animals, however, the animals are usually asymptomatic. The mode of transmission is from kittens that are teething, or lose their teeth and lick their paws, and then subsequently break the skin of a human via a scratch or a bite. It is also thought that the cat flea transmits this organism from kitten to kitten, and may directly transmit to humans [2,3].

Children and teenagers make up approximately $80 \%$ of patients diagnosed with CSD [4]. Bartonella osteomyelitis frequently occurs in the spine and presents with pain or tenderness in the affected area [5]. Osteomyelitis is usually diagnosed via magnetic resonance imaging (MRI) or radionuclide bone scanning. Additionally, clinicians must rely on serologic testing to identify Bartonella henselae, since the causative organism does not grow in culture [6]. We present an atypical case of CSD with vertebral osteomyelitis after possible cat exposure in an immunocompetent patient.

\section{Case Report}

A healthy 5-year-old male with a non-contributory past medical history, presented with worsening back pain and intermittent tactile fevers, along with acute ataxia and left head tilt. Three weeks prior to his admission he complained of generalized back pain with difficulty walking. Ibuprofen did not relieve the pain. This continued for 2 weeks, during which time he had intermittent fevers; a painful left groin lump was noticed about a week and a half after the back pain started. The left groin lump did not have any surrounding erythema, fluctuance or drainage.

During his initial ER visit on May 14th, 2019, vital signs were notable for an oral temperature of $98.6 \mathrm{~F}$, pulse of 109 , respiratory rate 20 , Blood Pressure $89 / 55$, an oxygen saturation of $100 \%$ on room air, and weight of $21.7 \mathrm{~kg}$. His exam was notable for generalized tenderness to palpation along the entire back, shotty inguinal lymphadenopathy, a 2 $\mathrm{cm} \times 3 \mathrm{~cm}$ tender mass in the left inguinal region, and a $3 \mathrm{~mm}$ pustule on the left heel with some purulent drainage. He had no focal neurological deficits, and his gait was steady. Basic labs, spinal x-ray and Ultrasound of the left groin mass were obtained (Table 1).

*Corresponding author: Rebecca Miller, New York Presbyterian Hospital Weill Cornell, Department of Pediatrics, Division of NeonatalPerinatal Medicine, 1283 York Avenue, DHK-1500, New York, NY, 10065; Tel: 917-504-6399, E-mail: rebeccamiller326@gmail.com

Accepted: July 08, 2021

Published online: July 10, 2021

Citation: Rebecca M, Sinduja L, Bernard G, et al. (2021)Ataxic Gait and Back Pain in an Immunocompetent 5-Year-Old Boy. Clin Pediatr Res 5(1):89-94 
The family was given an initial diagnosis of lymphadenitis and discharged home.

Following his discharge, he continued to have back pain not relieved with Ibuprofen. Over the course of two weeks, his back pain worsened, such that he was unable to ambulate. Despite round the clock analgesia, he had no relief. He developed a noticeable head tilt and limping gait one week after his first ER visit. Due to the new developments, he was referred to the ER by his primary care provider for immediate evaluation of a malignancy. The family denied any travel history, trauma, neurological deficits, weight loss, night sweats, headache, bowel or urinary incontinence, sick contacts, or any other system involvement. Of note, the family had recently acquired a cat, but denied any scratches or bites.

Upon the second presentation to the ER on May 21, 2019, vital signs notable for a temperature of $97.7 \mathrm{~F}$, pulse of 112 , respiratory rate of 24 , blood pressure of $104 / 72$, an oxygen saturation of $100 \%$ on room air, and weight recorded as 21.8 $\mathrm{kg}$. His exam in the ER was notable for an ataxic gait and leftsided head tilt while ambulating. Additionally, he had a $2 \mathrm{~cm}$ $\times 2 \mathrm{~cm}$ tender mass in the left groin, that was mobile, nontender, and without overlying erythema, edema, warmth, or discoloration. Laboratory tests and additional imaging (Table 2) were done and he was admitted to the General Pediatric Inpatient Unit to rule out a malignancy.

There was a wide differential diagnosis (Table 3).

Table 1: This table outlines the initial laboratory testing that was done when the patient first presented to the ER after having symptoms (generalized back pain, and intermittent fevers) for 2 week and a newly presented left groin lump.

\begin{tabular}{|c|c|}
\hline $\begin{array}{l}\text { Laboratory testing/Radiologic } \\
\text { work-up }\end{array}$ & Results \\
\hline Complete Blood Count & $\begin{array}{l}\text { White blood cell count: } 10.69 / \mathrm{nL} \\
\text { Segmented Neutrophils: } 48 \% \\
\text { Lymphocytes: } 38.4 \% \\
\text { Monocytes: } 9.8 \% \\
\text { Eosinophils: } 2.8 \% \\
\text { Hemoglobin: } 12.3 \mathrm{~g} / \mathrm{dL} \\
\text { Hematocrit: } 36.5 \%\end{array}$ \\
\hline Complete Metabolic Panel & $\begin{array}{l}\text { Sodium: } 139 \mathrm{mEq} / \mathrm{L} \\
\text { Potassium: } 4.5 \mathrm{mEq} / \mathrm{L} \\
\text { Chloride: } 101 \mathrm{mEq} / \mathrm{L} \\
\text { Bicarbonate: } 26.5 \mathrm{mEq} / \mathrm{L} \\
\text { Blood Urea Nitrogen: } 9 \mathrm{mg} / \mathrm{dL} \\
\text { Creatinine: } 0.5 \mathrm{mg} / \mathrm{dL} \\
\text { Calcium: } 9.1 \mathrm{mg} / \mathrm{dL} \\
\text { Glucose: } 92 \mathrm{mg} / \mathrm{dL} \\
\text { Albumin: } 4.1 \mathrm{~g} / \mathrm{dL} \\
\text { Total Protein: } 6.8 \mathrm{~g} / \mathrm{dL} \\
\text { Total bilirubin: } 0.3 \mathrm{mg} / \mathrm{dL} \\
\text { Alanine Transaminase: } 63 \mathrm{U} / \mathrm{L} \\
\text { Aspartate Aminotransferase: } \\
33 \text { U/L } \\
\text { Alkaline Phosphatase: } 180 \mathrm{U} / \mathrm{L}\end{array}$ \\
\hline Spinal X-ray & Normal studies \\
\hline Ultrasound of the left groin & $\begin{array}{l}\text { Enlarged lymph node without a } \\
\text { fluid collection }\end{array}$ \\
\hline
\end{tabular}

Table 2: This table represents the work-up that was done for the evaluation of this patient's symptoms when he presented to the ER for the second time.

\begin{tabular}{|c|c|}
\hline $\begin{array}{l}\text { Laboratory Testing/Radiologic } \\
\text { Work-Up }\end{array}$ & Results \\
\hline Complete Blood Count & $\begin{array}{l}\text { White blood cell count: } 11.33 \text { /nL } \\
\text { Segmented Neutrophils: } 57.9 \% \\
\text { Lymphocytes: } 32.7 \% \\
\text { Monocytes: } 7.4 \% \\
\text { Eosinophils: } 1.1 \% \\
\text { Hemoglobin: } 12.4 \mathrm{~g} / \mathrm{dL} \\
\text { Hematocrit: } 37.5 \%\end{array}$ \\
\hline Complete Metabolic Panel & $\begin{array}{l}\text { Sodium: } 141 \mathrm{mEq} / \mathrm{L} \\
\text { Potassium: } 4.5 \mathrm{mEq} / \mathrm{L} \\
\text { Chloride: } 102 \mathrm{mEq} / \mathrm{L} \\
\text { Bicarbonate: } 25 \mathrm{mEq} / \mathrm{L} \\
\text { Blood Urea Nitrogen: } 8 \mathrm{mg} / \mathrm{dL} \\
\text { Creatinine: } 0.4 \mathrm{mg} / \mathrm{dL} \\
\text { Calcium: } 9.9 \mathrm{mg} / \mathrm{dL} \\
\text { Glucose: } 103 \mathrm{mg} / \mathrm{dL} \\
\text { Albumin: } 4.5 \mathrm{~g} / \mathrm{dL} \\
\text { Total Protein: } 7.6 \mathrm{~g} / \mathrm{dL} \\
\text { Total bilirubin: } 0.2 \mathrm{mg} / \mathrm{dL} \\
\text { Alanine Transaminase: } 56 \mathrm{U} / \mathrm{L} \\
\text { Aspartate Aminotransferase: } \\
39 \text { U/L } \\
\text { Alkaline Phosphatase: } 229 \mathrm{U} / \mathrm{L}\end{array}$ \\
\hline C-Reactive Protein & $8.3 \mathrm{mg} / \mathrm{L}$ \\
\hline Erythrocyte Sedimentation Rate & $58 \mathrm{~mm} / \mathrm{h}$ \\
\hline Heterophile Ab Screen & Negative \\
\hline EBV Ab Panel & IgM Negative, IgG Positive \\
\hline Uric Acid & $2.4 \mathrm{mg} / \mathrm{dL}$ \\
\hline $\mathrm{LDH}$ & $359 \mathrm{U} / \mathrm{L}$ \\
\hline CK & $96 \mathrm{U} / \mathrm{L}$ \\
\hline Abdominal X-ray & $\begin{array}{l}\text { Calcifications in the left upper } \\
\text { quadrant }\end{array}$ \\
\hline Chest X-Ray & Normal chest radiograph. \\
\hline Abdominal Ultrasound & $\begin{array}{l}\text { Multiple tiny hypoechoic lesions } \\
\text { within the spleen, which was } \\
\text { not enlarged for the patients } \\
\text { age. Suspect } 2 \text { hypoechoic } \\
\text { lesions in the liver, otherwise } \\
\text { liver demonstrates normal size, } \\
\text { contour and echotexture. }\end{array}$ \\
\hline
\end{tabular}

Pediatric neurology was consulted first, due to the concern of a possible posterior fossa malignancy. On their exam, they noted point tenderness at the level of the second thoracic vertebra and bilateral foot clonus, in addition to a left sided-head tilt. A non-contrast head CT was performed and was negative.

Due to findings of lymphadenopathy, Epstein-Barr virus, cytomegalovirus, QuantiFERON-Gold test, and $B$. henselae antibodies were measured. CT spine was obtained and demonstrated minor soft tissue changes around the T2 vertebra, that was better characterized by an MRI of the spine which showed hyper-intensity of the T2 vertebral body (Figure 1).

As imaging was negative for a possible malignancy, no additional treatment was started. The $B$. henselae titers returned on hospital day 8 and he was started on dual therapy 
Table 3: This table outlines the differential diagnosis for the patient when he first arrived at the pediatric inpatient unit.

\begin{tabular}{|c|c|c|c|c|c|}
\hline System & $\begin{array}{l}\text { Differential } \\
\text { Diagnosis }\end{array}$ & Common Presentation & Investigation & Likelihood in our Patient & Treatment \\
\hline Neurology & $\begin{array}{l}\text { Posterior Fossa } \\
\text { Malignancy }\end{array}$ & $\begin{array}{l}\text {-Head-tilt } \\
\text {-Headache } \\
\text {-Herniation (respiratory } \\
\text { depression, } \\
\text { bradycardia) }\end{array}$ & -CT and MRI of the brain & $\begin{array}{l}\text { Unlikely - repeat exam } \\
\text { noted bilateral foot clonus, } \\
\text { ataxic gait and left-sided } \\
\text { head tilt, but imaging } \\
\text { negative }\end{array}$ & $\begin{array}{l}\text {-Surgery } \\
\text {-Chemotherapy and } \\
\text { Radiation }\end{array}$ \\
\hline \multirow[t]{4}{*}{$\begin{array}{l}\text { Hematology } \\
\text { / Oncology }\end{array}$} & Lymphoma & $\begin{array}{l}\text {-Night sweats } \\
\text {-Pruritus } \\
\text {-Weight loss } \\
\text {-Cough } \\
\text {-Lymphadenopathy } \\
\text { (non-tender) }\end{array}$ & $\begin{array}{l}\text {-CBC (normal or high WBC) } \\
\text {-Bone marrow biopsy } \\
\text {-Chest x-ray } \\
\text {-Excision of the lymph node }\end{array}$ & $\begin{array}{l}\text { Unlikely - patient } \\
\text { had regional tender } \\
\text { lymphadenopathy, no } \\
\text { history of cough, weight } \\
\text { loss or night sweats }\end{array}$ & $\begin{array}{l}\text {-Chemotherapy and } \\
\text { Radiation } \\
\text {-Surgery }\end{array}$ \\
\hline & Leukemia & $\begin{array}{l}\text {-Bone pain } \\
\text {-Weight loss } \\
\text {-Fever } \\
\text {-Poor appetite } \\
\text {-Bleeding } \\
\text {-Bruising } \\
\text {-Infections }\end{array}$ & $\begin{array}{l}\text {-CBC (high or low WBC, low } \\
\text { Hb or Plt) } \\
\text {-BMP (high potassium) } \\
\text {-LDH (elevated in Tumor } \\
\text { Lysis Syndrome) } \\
\text {-Uric Acid (Elevated in } \\
\text { Tumor Lysis Syndrome) } \\
\text {-Bone marrow biopsy }\end{array}$ & $\begin{array}{l}\text { Unlikely - normal white } \\
\text { count, slightly elevated } \\
\text { LDH to } 359 \text {, normal uric } \\
\text { acid, no weight loss, or } \\
\text { change in appetite }\end{array}$ & $\begin{array}{l}\text {-Chemotherapy (induction } \\
\text { and maintenance) }\end{array}$ \\
\hline & $\begin{array}{l}\text { Neuroblastoma } \\
\text { with osseous } \\
\text { metastases }\end{array}$ & $\begin{array}{l}\text {-Nystagmus } \\
\text {-Purple hue to eyelid } \\
\text {-Possible ecchymosis to } \\
\text { periorbital area } \\
\text {-Abdominal Pain }\end{array}$ & $\begin{array}{l}\text {-Elevated ferritin } \\
\text {-Elevated LDH } \\
\text {-Urine VMA may be elevated } \\
\text {-Bone Marrow Biopsy } \\
\text {-CT/MRI } \\
\text {-MIBG scan }\end{array}$ & $\begin{array}{l}\text { Likely - given age and sex, } \\
\text { but without abnormal eye } \\
\text { movements, abdominal } \\
\text { pain, and abdominal } \\
\text { imaging negative for mass }\end{array}$ & $\begin{array}{l}\text {-Surgical Resection } \\
\text {-Chemotherapy } \\
\text {-Radiation } \\
\text {-Antibody medicines } \\
\text { (Naxitamab or } \\
\text { Omburtamab) }\end{array}$ \\
\hline & Spinal Tumor & $\begin{array}{l}\text {-Back Pain } \\
\text {-Neuropathy from } \\
\text { compression } \\
\text {-Incontinence } \\
\text {-Ataxic Gait }\end{array}$ & -CT and MRI of the spine & $\begin{array}{l}\text { Less likely - given age, no } \\
\text { incontinence, although } \\
\text { patient had back pain and } \\
\text { ataxic gait }\end{array}$ & $\begin{array}{l}\text {-Surgery } \\
\text {-Chemotherapy } \\
\text {-Radiation }\end{array}$ \\
\hline \multirow[t]{4}{*}{$\begin{array}{l}\text { Infectious } \\
\text { Disease }\end{array}$} & $\begin{array}{l}\text { Cat-Scratch } \\
\text { Disease }\end{array}$ & $\begin{array}{l}\text {-Regional } \\
\text { lymphadenopathy +/- } \\
\text { drainage } \\
\text {-Fever } \\
\text {-Scratches or bites } \\
\text {-Back Pain }\end{array}$ & -Bartonella IgM Serology & $\begin{array}{l}\text { Likely - had point } \\
\text { tenderness at T2, } \\
\text { pustule on left heel } \\
\text { from first ER visit, left } \\
\text { groin lymphadenopathy, } \\
\text { possible cat exposure } \\
\text { at home, CT showed } \\
\text { enhancement at T2 }\end{array}$ & $\begin{array}{l}\text {-No need to treat, } \\
\text { unless patient is } \\
\text { immunocompromised or } \\
\text { with severe disease } \\
\text {-Treat with macrolides, } \\
\text { doxycycline, TMP-SMX, } \\
\text { and gentamicin }\end{array}$ \\
\hline & $\begin{array}{l}\text { Tuberculosis } \\
\text { (Pott's Disease) }\end{array}$ & $\begin{array}{l}\text {-Cough } \\
\text {-Night sweats } \\
\text {-Hemoptysis } \\
\text {-Fever } \\
\text {-Back Pain } \\
\text {-Spinal deformity }\end{array}$ & $\begin{array}{l}\text {-Positive QuantiFERON- } \\
\text { Gold test } \\
\text {-AFB smears of sputum/ } \\
\text { secretions } \\
\text {-Positive PPD }\end{array}$ & $\begin{array}{l}\text { Unlikely - chest xray and } \\
\text { initial spinal imaging } \\
\text { negative, no history } \\
\text { of exposure, negative } \\
\text { quantiferon }\end{array}$ & $\begin{array}{l}\text {-Rifampin } \\
\text {-Isoniazid + pyridoxine (for } \\
\text { possible neuropathy) } \\
\text {-Ethambutol }\end{array}$ \\
\hline & EBV & $\begin{array}{l}\text {-Sore throat } \\
\text {-URI symptoms } \\
\text {-Fatigue } \\
\text {-Abdominal Pain } \\
\text {-Fever } \\
\text {-Lymphadenopathy }\end{array}$ & $\begin{array}{l}\text {-Viral Capsid Antigen } \\
\text {-Monospot } \\
\text {-EBV IgM and IgG titers } \\
\text {-CBC (atypical } \\
\text { lymphocytes) }\end{array}$ & $\begin{array}{l}\text { Unlikely - patient had } \\
\text { regional lymphadenopathy } \\
\text { only, no URI symptoms } \\
\text { or abdominal pain, EBV } \\
\text { serology negative }\end{array}$ & -Supportive care \\
\hline & CMV & $\begin{array}{l}\text {-Sore throat } \\
\text {-URI symptoms } \\
\text {-Fatigue } \\
\text {-Abdominal Pain } \\
\text {-Fever } \\
\text {-Lymphadenopathy }\end{array}$ & -CMV IgM and IgG titers & $\begin{array}{l}\text { Unlikely - Patient had } \\
\text { regional lymphadenopathy } \\
\text { only, no URI symptoms or } \\
\text { abdominal pain, and CMV } \\
\text { serology negative }\end{array}$ & -Supportive care \\
\hline
\end{tabular}




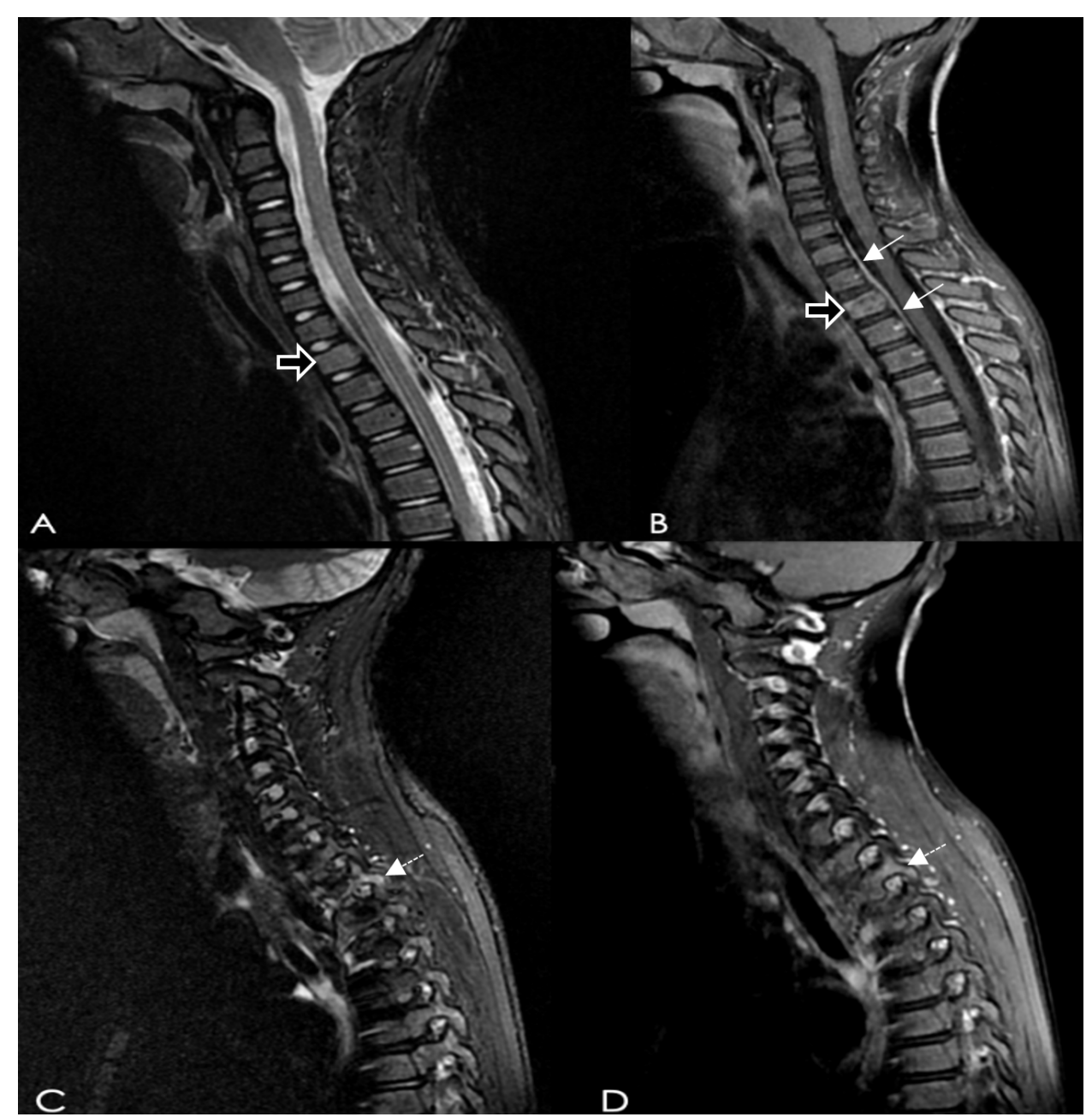

Figure 1: Images A and B are Sagittal midline MRI images of the cervical spine (fat suppressed inversion recovery and fat suppressed T1 weighted image following the administration of intravenous contrast) demonstrate high signal indicating subtle edema and enhancement of the T2 vertebral body respectively (open $\rightarrow$ ). The intervertebral discs demonstrate normal height and signal. Linear enhancement along the anterior dural space (solid $\rightarrow$ ) from C6 to T3 represents engorged dural veins reactive to the process at T2. Images $C$ and $D$ represent the sagittal right of midline MRI images of the cervical spine (fat suppressed inversion recovery and fat suppressed T1 weighted image following the administration of intravenous contrast) demonstrate similar high signal in the right inferior facet of T3 (dashed $\rightarrow$ ).

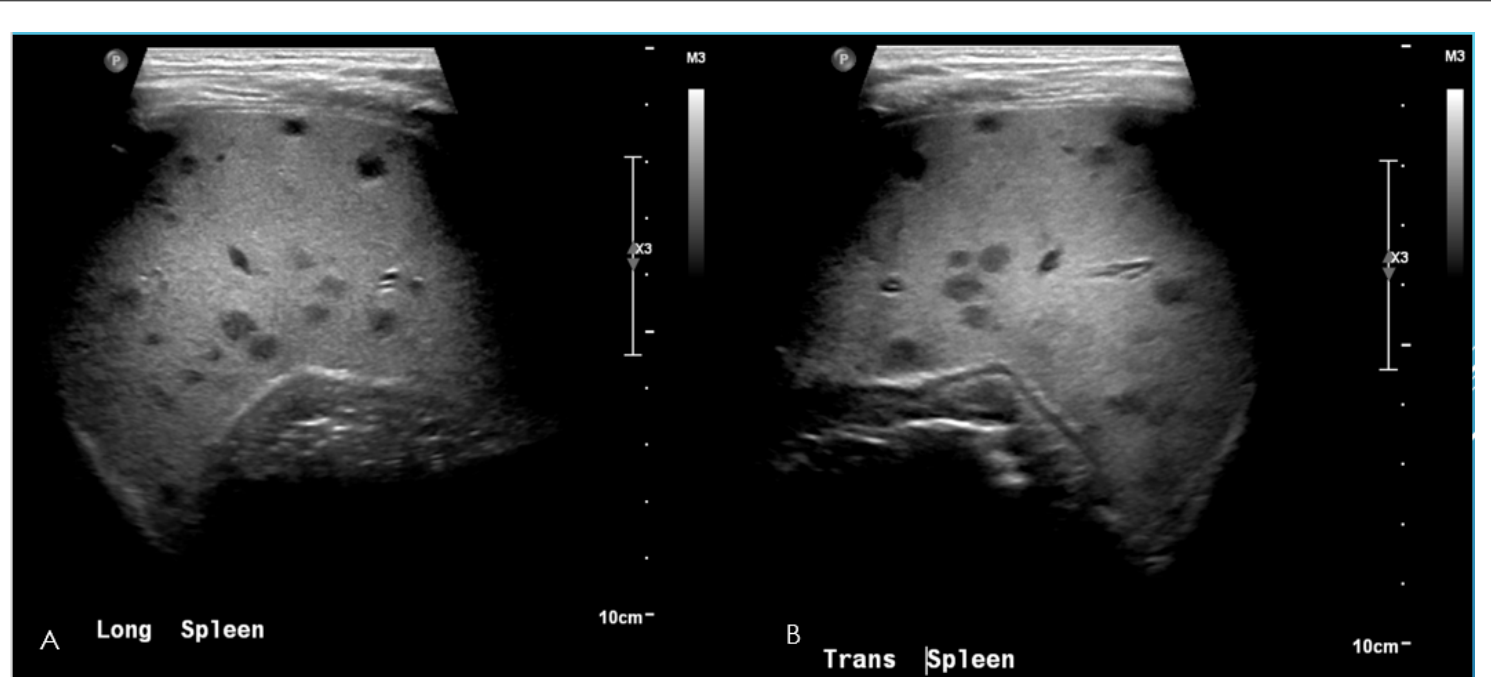

Figure 2: Longitudinal (a) and transverse (b) grayscale sonographic images of the spleen demonstrate multiple hypoechoic nodules representing granulomas related to Bartonella henselae infection. 
Citation: Rebecca M, Sinduja L, Bernard G, et al. (2021)Ataxic Gait and Back Pain in an Immunocompetent 5-Year-Old Boy. Clin Pediatr Res $5(1): 89-94$

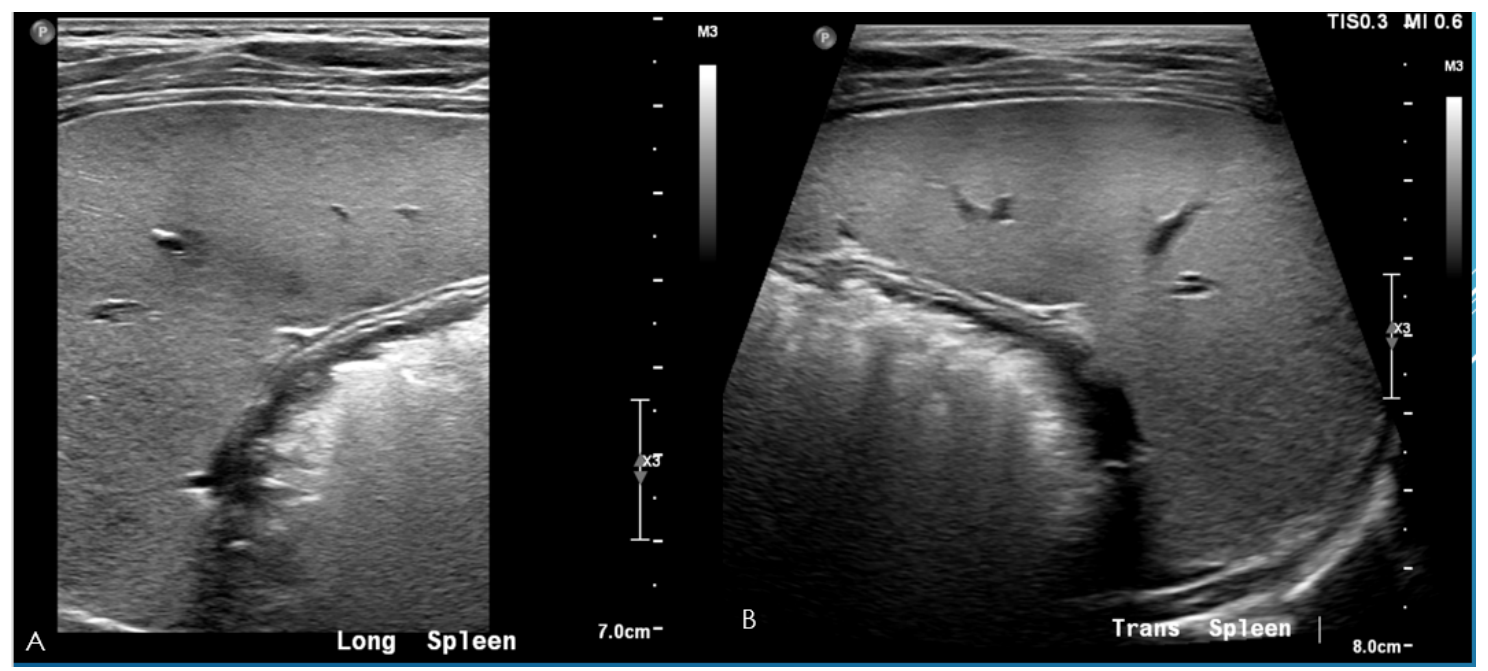

Figure 3: Longitudinal (a) and transverse (b) grayscale sonographic images of the spleen obtained 7 weeks after initiation of treatment demonstrate near complete resolution with interval decrease in size and conspicuity of the nodules.

of Rifampin and Azithromycin, as his titers were suggestive of an infection ( $\lg G>1: 1024$, $\lg M>1: 20$ ). Due to the possible hepatic involvement of $B$. henselae a repeat abdominal ultrasound was performed showing multiple liver and splenic lesions, compatible with disseminated $B$. henselae infection (Figure 2).

This confirmed the granulomatous inflammation that is seen with atypical CSD. Due to disseminated infection, he was started on Azithromycin and Rifampin. His back pain improved and he was discharged home on hospital day 11 to complete a total 8-week course of treatment. He and his mother were happy with his improvement.

He had regular follow-up visits with Infectious Disease and had a repeat abdominal ultrasound on week 7 of treatment, showing near complete resolution of the splenic and liver nodules (Figure 3), consistent with resolving infection. Additionally, repeat Bartonella henselae serology testing performed at week 7 were notable for negative IgM titers $(<1: 20)$, and positive IgG titers $(=/>1: 1024)$ which was suggestive of a resolving infection.

\section{Discussion}

CSD has a variable presentation from regional lymphadenopathy distal to the site of inoculation, fever of unknown origin (FUO), to various organ involvement, which can lead to an atypical presentation. One's immune status can play a role in how a disease may present. Perinatal and postnatal exposures to environmental agents have been thought to affect the immune system "programming" and consequently may effect disease presentation [7]. In an immunocompetent person, the predominant manifestation of CSD is regional lymphadenopathy [8]. Based on history obtained and review of the medical record, there was no evidence for this patient's immune status being compromised [7]. Atypical presentations range from abscesses, Parinaud oculoglandular syndrome, osteomyelitis, encephalitis, or a rash $[9,10]$. Approximately $10 \%$ of patients with CSD will develop hepatosplenic disease, and bone involvement occurs in up to $0.27 \%$ in all cases of CSD [11]. Our patient initially presented with fever of unknown origin (defined as fever > $38.3^{\circ} \mathrm{C}\left(101^{\circ} \mathrm{F}\right)$ of at least 8 days duration, in which no diagnosis is apparent after initial outpatient or hospital evaluation, that includes a careful history and physical examination and initial laboratory assessment) [12].

Although there was denial of a cat scratch or bite, the pustule on the left heel could have been from a minor injury from the cat at home that was not brought to the mother's attention. The location of the pustule and the left groin lymphadenopathy is consistent with the expected regional lymphadenopathy with the initial presentation CSD. The incubation period of $B$. henselae from the time an individual is scratched to the appearance of a lesion iss 3-12 days, and from there, lymphadenopathy can occur, on average, after 12 days [1]. Our patient's initial presentation to the ER with regional (inguinal) lymphadenopathy, was a typical presentation of CSD, however, the diagnosis was missed as the history was misleading.

CSD-related osteomyelitis is uncommon, however, when it does occur, it commonly affects the pelvic girdle and vertebral column as was seen in our patient.

In addition, our patient also had radiographic evidence of lesions in the liver, which could have been bacillary angiomatosis. This occurs when certain Bartonella spp, such as $B$. henselae cause angioproliferative lesions which are made up of proliferating endothelial cells and bacteria. Although it is still not clear what role Bartonella plays at the molecular level, the resolution of these lesions after the initiation of antibiotic treatment, points toward Bartonella's primary role in their formation [13].

The diagnosis is usually suspected based on the history, especially if there is involvement of a kitten. The diagnosis of CSD is confirmed with positive Bartonella IgM serology. The elevation of IgM is often short lived and IgM titers may remain normal during the course of the disease. As such, elevated IgM is only identified in $50 \%$ of people due to its short duration. IgG titers are often greater than 1:256 and are typically indicative of previous or active disease [14]. 
Bartonella IgG may remain seropositive for up to a year (in $25 \%$ of patients), making it difficult to determine if there is an active or previous infection. At present, confirmation of the diagnosis is via PCR testing, as it is nearly $100 \%$ specific [5].

When treated with antibiotics or surgery, the prognosis is excellent $[15,16]$. Treatment options include trimethoprim-sulfamethoxazole, erythromycin, clarithromycin, azithromycin, rifampin, doxycycline (if over 8 years old), ciprofloxacin, and gentamicin [1].

\section{Conclusion}

In conclusion, $B$. henselae is a rare cause of pediatric osteomyelitis and disseminated disease and should be considered in those patients who have had possible exposure to a kitten. CSD can have a varied presentation and is usually considered the primary diagnosis where there is possible cat exposure. However, it often goes undiagnosed due to nonspecific signs and symptoms associated with the disease, and its usually self-limited course. Our patient's history of significant cat exposure, elevated anti-B. henselae IgG and IgM titers, imaging confirming involvement of bone, spleen and liver, supported our diagnosis of CSD. To our knowledge, this is the first case report evaluating the efficacy of Azithromycin and Rifampin in the treatment of a patient with confirmed Bartonella osteomyelitis and hepatosplenic involvement.

\section{Author Disclosure}

Drs. Miller, Lakkunarajah, and Goldwasser have disclosed no financial relationships relevant to this article to disclose. This commentary does not contain a discussion of an unapproved/investigative use of a commercial product/ device. Dr. Lakkunarajah's current affiliation is Medical College of Wisconsin Affiliated Hospitals, Department of Pediatrics, Division of Adolescent Medicine, Milwaukee, WI. Dr. Miller's current affiliation is New York-Presbyterian Hospital Weill Cornell, Department of Pediatrics, Division of Neonatal-Perinatal Medicine, New York, NY.

\section{References}

1. Kimberlin DW, Brady MT, Jackson MA (2018) Summaries of Infectious Diseases. In: Red Book. (31st edn), Committee on Infectious Diseases, American Academy of Pediatrics, 244-247.
2. Zangwill KM, Hamilton DH, Perkins BA, et al. (1993) Cat scratch disease in connecticut. Epidemiology, risk factors, and evaluation of a new diagnostic test. N Engl J Med 329: 8-13.

3. Abdel-Haq N, Abuhammour W, Al-Tatari H, et al. (2005) Disseminated cat scratch disease with vertebral osteomyelitis and epidural abscess. South Med J 98: 1142-1145.

4. Garcia JC, Nunez MJ, Castro B, et al. (2014) Hepatosplenic cat scratch disease in immunocompetent adults. Medicine 93: 267-279.

5. Mazur-Melewska K, Jończyk-Potoczna K, Mania A, et al. (2015) The significance of bartonella henselae bacterias for oncological diagnosis in children. Infect Agent Cancer 10: 30.

6. S Joychan, Y Kuchipudi, P Danielsky, et al. (2017) Case of nonspinal osteomyelitis due to Bartonella and review of the literature. Infectious Diseases in Clinical Practice 25: 240-242.

7. Duramad P, Tager IB, Holland NT (2007) Cytokines and other immunological biomarkers in children's environmental health studies. Toxicol Lett 172: 48-59.

8. Hussain S, Rathore MH (2007) Cat scratch disease with epidural extension while on antimicrobial treatment. Pediatr Neurosurg 43: 164-166.

9. C Dehio (2004) Molecular and cellular basis of bartonella pathogenesis. Annu Rev Microbiol 58: 365-390.

10. JW Bass, JM Vincent, DA Person (1997) The expanding spectrum of Bartonella infections: II. Cat-scratch disease. Pediatr Infect Dis J 16: 163-179.

11. Dona D, Fovino LN, Mozzo E, et al. (2018) Osteomyelitis in catscratch disease: A never-ending dilemma-a case report and literature review. Case Rep Pediatr 2018: 1-8.

12. Jacobs RF, Schutze GE (1998) Bartonella henselae as a cause of prolonged fever and fever of unknown origin in children. Clin Infect Dis 26: 80-84.

13. Kirby JE, Nekorchuk DM (2002) Bartonella-associated endothelial proliferation depends on inhibition of apoptosis. Proc Natl Acad Sci U S A 99: 4656-4661.

14. Klotz SA, lanas V, Elliot SP (2011) Cat-scratch disease. American Family Physician 83: 152-155.

15. Tasher D, Armarnik E, Mizrahi A, et al. (2009) Cat scratch disease with cervical vertebral osteomyelitis and spinal epidural abscess. Pediatr Infect Dis J 28: 848-850.

16. Rolain JM, Chanet V, Laurichesse H, et al. (2003) Cat scratch disease with lymphadenitis, vertebral osteomyelitis, and spleen abscesses. Ann N Y Acad Sci 990: 397-403.

DOI: $10.36959 / 395 / 514$

Copyright: (c) 2021 Rebecca M. This is an open-access article distributed under the terms of the Creative Commons Attribution License, which permits unrestricted use, distribution, and reproduction in any medium, provided the original author and source are credited. 